\title{
Jolanta Adamiec Finansowanie badań naukowych z budżetu Unii Europejskiej. Wnioski dla Polski
}

\section{Financing scientific research from the budget of the European Union}

The article explores the approach of the European Union to financing of scientific research. It begins by outlining strategic documents of the EU concerning research policy and developments in financial support addressed to this kind of activities. More attention is given to the two consecutive cycles of European funding - Horizon 2020, which is currently coming to an end, and Horizon Europe, the programming phase of which is now being finalized. The review of the above issues serves as a basis for discussion how Poland uses the possibilities of financial support for scientific research and development activities and how the efficiency of Polish scientific institutions in applying for the EU funds could be improved.

\begin{tabular}{r|l}
\hline DOI & https://doi.org/10.31268/StudiaBAS.2020.03 \\
\hline Słowa kluczowe & $\begin{array}{l}\text { badania naukowe, polityka naukowa Unii Europejskiej, programy } \\
\text { ramowe, „Horyzont 2020”, ,Horyzont Europa”, granty badawcze }\end{array}$ \\
\hline Keywords & $\begin{array}{l}\text { scientific research, EU scientific policy, framework programmes, } \\
\text { Horizon 2020, Horizon Europe, research grants }\end{array}$ \\
\hline 0 autorce & $\begin{array}{l}\text { Doktor nauk ekonomicznych, specjalista ds. systemu gospodarczego } \\
\text { W BAS } \bullet \text { jolanta.adamiec@sejm.gov.pl } \\
\text { ORCID 0000-0003-1107-6492 }\end{array}$ \\
\hline
\end{tabular}

\section{Wstęp}

We współczesnej gospodarce rozwój w coraz większym stopniu uzależniony jest od wiedzy, a na początku lat 90. XX wieku naukowcy zaczęli używać pojęcia „gospodarka oparta na wiedzy"1. OECD zdefiniowała to pojęcie jako: wyrażenie ukute (coined) w celu opisania trendów w zaawansowanych gospodarkach w kierunku większej zależności od wiedzy, informacji i wysokich umiejętności oraz rosnqcej potrzeby szybkiego dostępu do nich przez biznes i sektor publiczny². Oznacza to, że klasyczne czynniki wytwórcze (ziemia, praca i kapitał) straciły swoją pierwszoplanową rolę, kluczowe natomiast stało się inwestowanie w wiedzę. Przewagę konkurencyjną w globalnej gospodarce uzyskują te państwa, które szybciej są w stanie przeprowadzić transformację w kierunku gospodarki opartej na wiedzy, a służy temu przede wszystkim rozwijanie działalności badawczo-rozwojowej $(B+R)^{3}$. Wymaga to znacznych nakładów finansowych. W efekcie wydatki

1 D. Makulska, Kluczowe czynniki rozwoju w gospodarce opartej na wiedzy, „Prace i Materiały Instytutu Rozwoju Gospodarczego SGH" 2012, t. 88, s. 170, http://www.sgh.waw.pl/instytuty/irg/publikacje/pimirg [dostęp: 10 lutego 2020 r.].

2 The Measurement of Scientific and Technological Activities: Guidelines for Collecting and Interpreting Innovation Data: Oslo Manual, Third Edition, Working Party of National Experts on Scientific and Technology Indicators, OECD, Paris 2005, § 71, https://doi.org/10.1787/9789264013100-en.

3 A. Pollok, G. Wałęga, Kreowanie wiedzy w Polsce przez inwestowanie w badania i rozwój [w:] Inwestowanie w kapitał ludzki, red. S. Borkowska, Zakład Wydawnictw Statystycznych, Warszawa 2007, s. 36; M. Golińska-Pieszyńska, Polityka wiedzy a współczesne procesy innowacyjne, Wydawnictwo Naukowe Scholar, Warszawa 
na działalność badawczo-rozwojową stały się jednym z ważnych wskaźników potencjału rozwojowego zarówno gospodarki jako całości, jak i poszczególnych przedsiębiorstw ${ }^{4}$. Co za tym idzie, kluczowe stało się zapewnienie źródeł tego finansowania.

Na dość wczesnym etapie potrzebę taką dostrzegła Unia Europejska, uruchamiając programy finansowania prac badawczo-rozwojowych (programy ramowe), które stały się ważnym źródłem finansowania B+R w państwach członkowskich. Badacze wskazują, że w trzech najmniej rozwiniętych państwach - Grecji, Irlandii i Portugalii - wysokość procentowego udziału środków europejskich wynosiła od 10\% do 35\% całkowitych nakładów na działalność badawczą ${ }^{5}$. Zauważają przy tym, że szczególnie ważnym efektem oddziaływania programów ramowych był impuls do zacieśniania ponadnarodowej współpracy naukowej ${ }^{6}$. Z czasem polityka finansowania badań UE zmierzała nie tylko w kierunku transnarodowości, ale także interdyscyplinarności wspieranych projektów tak, aby skuteczniej odpowiadać na wyzwania współczesności i zwiększać europejską wartość dodaną7.

Polska, jako państwo członkowskie Unii Europejskiej, ma pełne możliwości dostępu do budżetu unijnego jako źródła dofinansowania działalności naukowo-badawczej. Polityka dystrybuowania środków UE na badania naukowe rządzi się jednak innymi regułami niż - najlepiej w naszym kraju znana - pomoc finansowa otrzymywana z europejskich funduszy strukturalnych na potrzeby rozwoju regionalnego czy ochrony środowiska. Fundusze na badania i rozwój nie są bowiem dzielone na tzw. koperty narodowe, lecz (w przeważającej części) rozdzielane na zasadzie konkursów, w których startują podmioty ze wszystkich państw członkowskich Unii na jednakowych zasadach (bez preferencji narodowych). Z tego względu istotna jest skuteczność podmiotów z Polski w pozyskiwaniu środków finansowych z tego źródła. Badania wskazywały, że sytuacja naszego kraju w konkursach programów europejskich przez pierwsze lata była bardzo zła, bowiem w szóstym programie ramowym odzyskaliśmy tylko nieco ponad połowę naszej „naukowej” składki, a wyniki siódmego programu ramowego były jeszcze gorsze (na poziomie $35-45 \%$ wniesionych wpłat).

Pojawia się zatem pytanie, czy ta sytuacja uległa zmianie. Analiza aktualnej skuteczności podmiotów z Polski w aplikowaniu o fundusze z programów finansowania działalności badawczo-rozwojowej realizowanych przez Unię Europejską ${ }^{9}$ jest głównym tematem badawczym

2009, s. 8; M. Diaconu, Business R\&D investments in the EU: Main dynamics and economic effects, „Theoretical and Applied Economics" 2019, Vol. XXVI, No 4(621), s. 20.

4 M.M. Grzelak, I. Laskowska, E. Reszko-Wójtowicz, The Importance of Research Development Expenditure for the Competitiveness of Manufacturing Enterprises in Poland. The Application of Panel Models, "Econometrics, Ekonometria" 2018, Vol. 22, s. 10, https://doi.org/10.15611/eada.2018.3.01

5 M. Boguta, A. Bylicki, Polityka naukowa, badawcza i rozwojowa Unii Europejskiej, Fundacja im. Wojciecha Świętosławskiego na Rzecz Wspierania Nauki i Rozwoju Potencjału Naukowego w Polsce, Gliwice 1998, s. 106.

6 Ibidem, s. 108.

7 I. Żukowska, Interdyscyplinarność w polityce badawczej Unii Europejskiej [w:] Studia europejskie. Wyzwania interdyscyplinarności, red. J. Czaputowicz, Wydawnictwa Uniwersytetu Warszawskiego, Warszawa 2014, s. 370.

8 J. Duszyński, M. Szumowski, Nauka w Polsce w obliczu nowej perspektywy finansowej UE 2014-2020 i nowego programu ramowego tej perspektywy - Horizon 2020, "Nauka” 2012, nr 2, s. 43.

9 W szczególności w świetle wstępnych rezultatów wykorzystania środków z programu „Horyzont 2020". 
niniejszego artykułu. Punktem wyjścia dla tej analizy będzie ogólne spojrzenie na to, jak w polityce Wspólnot Europejskich, a potem Unii Europejskiej, traktowane były badania naukowe jako takie - na ile obecne w niej były od początku procesów integracyjnych i jak zmieniało się ich znaczenie. Naturalną konsekwencją tej analizy jest kwestia, jak wraz z kształtowaniem się europejskiej polityki badawczo-rozwojowej zmieniało się podejście do finansowania tej działalności. Odpowiedź na pytanie, jak ewoluowała zarówno skala tego finansowania, jak i jego zakres merytoryczny i podmiotowy, ma charakter pomocniczy dla znalezienia słabych punktów aplikacji kierowanych przez podmioty z Polski. Analizie tej poświęcone są kolejne trzy punkty niniejszego opracowania. Jako szczególnie ważne z tego punktu widzenia odrębnie zostaną potraktowane założenia i kluczowe cele przyjęte dla dwóch ostatnich cykli finansowania europejskiego. Są to: finalizowany program „Horyzont 2020” oraz znajdujący się obecnie w końcowej fazie planowania program „Horyzont Europa”.

Tak zarysowane tło, odnoszące się z jednej strony do polityki unijnej w zakresie badań naukowych, a z drugiej strony - do praktyki finansowego wspierania ich rozwoju, pozwoli na porównanie faktycznego udziału poszczególnych państw członkowskich w wykorzystaniu środków finansowych przeznaczonych z budżetu Unii Europejskiej na wspieranie działalności badawczo-rozwojowej w jej państwach członkowskich. Szczególna uwaga poświęcona zostanie udziałowi w programie „Horyzont 2020". Na podstawie tych danych możliwe będzie udzielenie wstępnej odpowiedzi na postawione wyżej pytanie badawcze o ocenę bieżącej skuteczności podmiotów z Polski w pozyskiwaniu środków na B+R z funduszy europejskich. Drugim aspektem tego zagadnienia jest pytanie o potencjalny udział Polski w kolejnej edycji programu, czyli „Horyzont Europa". Spojrzenie na założenia tego programu pozwoli wskazać, jakich zmian należy się spodziewać w najbliższej przyszłości i jak ewentualnie należałoby się do nich dostosować. Pomoże to odpowiedzieć na pytanie, jakie działania mogą być podjęte, aby efektywność pozyskiwania środków na rozwijanie działalności badawczo-rozwojowej w Polsce mogła być systematycznie doskonalona. Jest to zasadniczy cel niniejszego artykułu, aczkolwiek należy podkreślić, że temat jest niezwykle złożony, zatem to opracowanie nie rości sobie pretensji do udzielenia jednoznacznych odpowiedzi na sformułowane wyżej pytania. Jest ono jedynie próbą zarysowania pewnych kierunków działań w celu poprawy dostępu polskiego sektora badań i rozwoju do europejskich źródeł finansowania tej działalności.

\section{Miejsce badań naukowych w polityce UE}

Badania naukowe uzyskały status oficjalnej polityki wspólnotowej dopiero w Jednolitym Akcie Europejskim, który był pierwszym oficjalnym dokumentem Wspólnot Europejskich zawierającym oddzielny rozdział poświęcony temu obszarowi współpracy. W nowym artykule $130 f$ stwierdzono wprost, że celem Wspólnoty będzie: wzmacnianie bazy naukowej i technologicznej europejskiego przemysłu i sprzyjanie zwiększaniu jego międzynarodowej konkurencyjności. Działaniami służącymi temu celowi miały być m.in.: realizacja programów badawczych we współpracy z przedsiębiorstwami i ośrodkami naukowymi, upowszechnianie wyników badań oraz popieranie kształcenia i mobilności naukowców we Wspólnocie, a podstawowym narzędziem realizacji 
tej polityki - wieloletni program ramowy, wskazujący zakres i zasady udziału finansowego Wspólnoty w prowadzeniu badań ${ }^{10}$.

W traktacie z Maastricht ${ }^{11}$ postanowienia dotyczące tego obszaru zostały rozwinięte jako tytuł XV - „Badania i rozwój technologiczny”, lecz główny cel był nadal skoncentrowany na rozwoju przemysłowym i w art. 130f został zdefiniowany jako: wzmacnianie podstaw naukowych i technologicznych przemysłu Wspólnoty. Przy czym rola Wspólnoty została ograniczona do uzupełniania działań prowadzonych przez państwa członkowskie, głównie przez realizowane programy badań, promowanie współpracy między przedsiębiorstwami, ośrodkami badawczymi i uniwersytetami, upowszechnienie wyników badań oraz stymulowanie mobilności naukowców.

Kolejnym krokiem na drodze pogłębionej koordynacji działalności naukowo-badawczej na poziomie europejskim był komunikat o europejskiej przestrzeni badawczej ${ }^{12}$ wydany przez Komisję Europejską 6 stycznia 2000 r. Komisja podkreśla w nim konieczność współpracy na poziomie ponadnarodowym, aby podnieść efektywność prowadzonych badań i ograniczyć dublowanie się prac, wskazując przy tym, że do tej pory jedynie 17\% środków publicznych przeznaczonych na rozmaite inicjatywy badawczo-naukowe nakierowanych było na współpracę na poziomie europejskim ${ }^{13}$. Jako narzędzia służące rozwijaniu tej płaszczyzny wskazano m.in. łączenie krajowych centrów doskonałości w sieci, transnarodowe budowanie i wykorzystanie infrastruktury badawczej, lepszą koordynację europejskich i krajowych programów badawczych, ustanowienie na poziomie europejskim wspólnego systemu referencji w celu ujednoliconej oceny metod, harmonizowania procedur i porównywania rezultatów badań, zwiększenie mobilności naukowców itp.

Kolejnym ważnym dokumentem Komisji poświęconym tej kwestii była zielona księga z kwietnia 2007 r. pt. Europejska Przestrzeń Badawcza: Nowe perspektywy ${ }^{14}$. Komisja dokonała w niej przeglądu działań związanych z europejską przestrzenią badawczą, wskazując, że nadal znaczne rozproszenie działań naukowo-badawczych uniemożliwia pełne wykorzystanie potencjału naukowo-badawczego i innowacyjnego, jakim dysponuje Unia Europejska. Komisja podkreśliła, że nieskoordynowane finansowanie krajowych i regionalnych badań naukowych (m.in. w zakresie programów, infrastruktury, finansowania instytucji naukowo-badawczych) prowadzi do rozproszenia zasobów, dublowania prac naukowo-badawczych czy utraty korzyści z potencjalnych wyników ubocznych. Jednym z istotnych negatywnych efektów braku harmonizacji badań na poziomie europejskim, wskazanym w tym dokumencie, są także trudności po stronie przedsiębiorców w nawiązaniu współpracy z instytucjami prowadzącymi badania naukowe w Europie, co automatycznie zmniejsza biznesową atrakcyjność regionu jako lokalizacji inwestycji badawczo-rozwojowych. W efekcie europejski potencjał badawczy nie odgrywa globalnej roli tak, jak to się dzieje w innych obszarach pogłębionej współpracy ${ }^{15}$.

10 Single European Act, OJ L 169 z 29 czerwca 1987 r., s. 10.

11 Traktat o Unii Europejskiej, Dz.U. 2004, nr 90, poz. 864/30.

12 Communication from the Commission to the Council, the European Parliament, the Economic And Social Committee and the Committee of the Regions: Towards a European research area, COM(2000) 6 final z 6 stycznia $2000 \mathrm{r}$.

13 Ibidem, s. 7.

14 Zielona księga. Europejska Przestrzeń Badawcza: Nowe perspektywy, COM(2007) 161 final z 4 kwietnia 2007 r.

15 Ibidem, s. 7-8. 
W zielonej księdze Komisja wskazała sześć kierunków działań, które miałyby doprowadzić do powstania europejskiej przestrzeni badawczej:

- stworzenie jednolitego rynku kadry naukowej,

- stworzenie światowej klasy infrastruktury naukowo-badawczej,

- wzmocnienie kondycji instytucji naukowo-badawczych,

- przepływ wiedzy,

- optymizacja programów i celów naukowo-badawczych,

- otwarcie na świat - międzynarodowa współpraca naukowo-technologiczna.

W traktacie lizbońskim działania te sformułowane zostały jednak znacznie ostrożniej. Polityka w zakresie badań naukowych została zdefiniowana w tytule XIX - „Badania i rozwój technologiczny oraz przestrzeń kosmiczna" (art. 179-190 wersji skonsolidowanej Traktatu o funkcjonowaniu Unii Europejskiej, TFUE). Jako zasadniczy cel działania Unii w tym zakresie wskazane zostało: wzmacnianie swojej bazy naukowej i technologicznej przez utworzenie europejskiej przestrzeni badawczej, w której naukowcy, wiedza naukowa i technologie podlegajq swobodnej wymianie, oraz sprzyjanie rozwojowi swojej konkurencyjności, także w przemyśle, a także promowanie działalności badawczej uznanej za niezbędną na mocy innych rozdziałów Traktatów ${ }^{16}$.

Narzędzia realizacji tego celu pozostały jednak zasadniczo niezmienione, koncentrując się na realizowaniu programów, promowaniu współpracy, upowszechnianiu wyników badań oraz mobilności naukowców. Nieco wzmocniony został jedynie akcent położony na ponadgraniczną współpracę naukowców, a kompetencje Komisji Europejskiej uzupełnione zostały o inicjatywy mające na celu określenie wytycznych i wskaźników, organizowanie wymiany najlepszych praktyk i przygotowanie elementów niezbędnych dla prowadzenia okresowego nadzoru i oceny. Zgodnie z postanowieniami traktatu lizbońskiego środki niezbędne do realizacji europejskiej przestrzeni badawczej mają jedynie stanowić uzupełnienie działań przewidzianych w wieloletnim programie ramowym (art. 182 TFUE), który pozostał podstawowym obszarem wspólnego działania.

Nadal jednak w Komisji Europejskiej toczyły się prace nad intensyfikacją współpracy w sferze badawczo-rozwojowej. W 2010 r. jako element strategii „Europa 2020” opublikowany został komunikat Komisji w sprawie Unii innowacji ${ }^{17}$, w którym podkreślono niedostateczne inwestowanie w podstawy wiedzy, a także fragmentację i kosztowną duplikację badań. W komunikacie Komisja wezwała między innymi do:

- Ściślejszego powiązania unijnych i krajowych systemów badań i innowacji,

- stworzenia takich samych możliwości pracy i współpracy badaczy i wynalazców w całej UE, jakie mają we własnym kraju,

- wzmocnienia roli Europejskiej Rady ds. Badań Naukowych,

16 Dz.U. 2009, nr 203, poz. 1569. Wersja skonsolidowana z 2016 r. Traktatu o Unii Europejskiej oraz Traktatu o funkcjonowaniu Unii Europejskiej zob. Dz.Urz. UE C 202 z 7 czerwca 2016 r.

17 Komunikat Komisji do Parlamentu Europejskiego, Rady, Europejskiego Komitetu Ekonomiczno-Społecznego oraz Komitetu Regionów: Projekt przewodni strategii Europa 2020: Unia innowacji, COM(2010) 546 final z 6 października $2010 \mathrm{r}$. 
- wprowadzenia systemu zachęt dla współpracy między światem nauki i biznesu,

- budowania europejskich partnerstw innowacji w celu przyspieszenia badań, rozwoju i rynkowej realizacji innowacji służących rozwiązywaniu głównych problemów społecznych, a także w celu łączenia zasobów i wiedzy specjalistycznej oraz zwiększania konkurencyjności przemysłu UE.

Stosunkowo szybko ruszyło pierwsze partnerstwo innowacji, które - zgodnie ze wskazaniem wspomnianego komunikatu - poświęcone jest zdrowej starości (European Innovation Partnership on Active and Healthy Ageing, EIP on $A H A^{18}$ ). Formalnie uruchomione w maju 2011 r. w lutym następnego roku uzyskało akceptację Komisji Europejskiej dla swojego planu strategicznego oraz zobowiązania co do rodzajów wsparcia na poziomie UE ${ }^{19}$. Obecnie istnieje sześć grup działania (Action Groups) poświęconych różnym aspektom starzenia się i przeciwdziałania związanym z tym problemom, w których zgłoszono blisko 1000 działań objętych współpracą. Drugą istotną formą wdrażania partnerstwa są centra referencyjne (Reference Sites). Są to regiony, miasta, szpitale lub organizacje opiekuńcze, które wraz z partnerami reprezentującymi sferę przemysłu, społeczeństwa obywatelskiego, środowiska akademickiego i administracji promują kompleksowe, innowacyjne podejście do aktywnego i zdrowego starzenia się. Centra takie wyłaniane są corocznie w wyniku konkursu. W 2019 r. 77 podmiotów uzyskało status centrum referencyjnego, w tym dwa z Polski (Szpital Specjalistyczny im. A. Falkiewicza we Wrocławiu oraz Uniwersytet Medyczny w Łodzi) ${ }^{20}$.

Zgodnie z założeniami komunikatu w sprawie Unii innowacji w ciągu czterech lat miała powstać europejska przestrzeń badawcza, tworząc ramy dla prawdziwie swobodnego przepływu wiedzy, a przede wszystkim gwarantując utrzymanie się Europy w gronie światowych liderów rozwoju gospodarczego. Założenia te nie do końca zostały spełnione, o czym świadczy kolejny komunikat Komisji w tej sprawie, postulujący przyspieszenie zmian ${ }^{21}$. Komisja wskazała w nim, że kryzys gospodarczy uwidocznił strukturalne słabości europejskiej innowacyjności, a jednym z zasadniczych problemów jest niewystarczający proces konwergencji państw członkowskich w dziedzinie innowacyjności, co rodzi ryzyko zwiększania, a nie zmniejszania przepaści innowacyjnej między nimi. Komisja podkreśliła, że żadne państwo członkowskie nie jest w stanie samodzielnie stworzyć innowacyjnej gospodarki, wezwała zatem do m.in. opracowania spójnego podejścia strategicznego sprzyjającego otwartej innowacyjności i transferowi wiedzy. Zapowiedziała także konieczność zapewnienia większej synergii między finansowaniem działalności badawczo-rozwojowej a funduszami strukturalnymi.

18 Https://ec.europa.eu/eip/ageing/home_en [dostęp: 5 listopada 2019 r.].

19 Komunikat Komisji do Parlamentu Europejskiego i Rady: Działania w ramach Strategicznego planu realizacji europejskiego partnerstwa na rzecz innowacji sprzyjajacej aktywnemu starzeniu się w dobrym zdrowiu, COM(2012) 83 final z 29 lutego $2012 \mathrm{r}$.

202019 Call for Reference Sites Results, European Innovation Partnership on Active and Healthy Ageing, European Commission, https://ec.europa.eu/eip/ageing/library/2019-call-reference-sites-results_en [dostęp: 5 listopada 2019 r.].

21 Komunikat Komisji do Parlamentu Europejskiego, Rady, Europejskiego Komitetu Ekonomiczno-Społecznego oraz Komitetu Regionów: Stan Unii innowacji na 2012 r. - przyśpieszenie zmian, COM(2013) 149 final z 21 marca 2013 r. 
Najnowszym dokumentem programowym, który ma stymulować dalsze pogłębianie unijnej polityki w zakresie badań, rozwoju i innowacji jest odnowiony europejski program na rzecz badań i innowacji ${ }^{22}$. Podkreśla się w nim, że w wielu dziedzinach Europa ma przewagę konkurencyjną - choć mieszkańcy Europy stanowią 7\% światowej populacji, to odpowiada ona za $20 \%$ globalnych inwestycji w badania i rozwój oraz około $1 \frac{1}{3}$ wszystkich publikacji naukowych wysokiej jakości. Problemem jest jednak to, że innowacyjne rozwiązania nie zawsze przekładają się na nowe możliwości rynkowe i szanse rozwoju, a Chiny i Stany Zjednoczone wyprzedzają Europę pod względem poziomu inwestycji w technologie, które prawdopodobnie będą odgrywać dominującą rolę w przyszłości. Rozwiązaniem ma być stworzenie silnego europejskiego ekosystemu badań naukowych i innowacji, łączącego różnych graczy, instrumenty i polityki na poziomie lokalnym, krajowym i europejskim w spójne środowisko sprzyjające badaniom naukowym i innowacji.

Takie założenia polityki unijnej mają oczywiście przełożenie na kształtowanie budżetu UE. W propozycji wieloletnich ram finansowych 2021-2027 Komisja wskazała, że badania naukowe i innowacje muszą pozostać podstawowym priorytetem i zaproponowała podwyższenie poziomu inwestycji w tym obszarze. Głównym narzędziem ma być program „Horyzont Europa”, lecz istotne będą również instrumenty rynkowe, w tym instrumenty finansowe i gwarancje budżetowe ze specjalnej puli funduszu InvestEU, które mają przyciągnąć inwestycje prywatne przeznaczone na realizację badań i innowacji. Ponadto większość programów finansowanych przez Unię ma zawierać kluczowe elementy składowe innowacji.

\section{Zasady finansowania badań naukowych z budżetu Unii Europejskiej}

Głównym instrumentem realizowania europejskiej polityki badawczo-rozwojowej jest finansowanie projektów, które odpowiadają założeniom wspólnie uzgodnionych celów. Pierwsze próby koordynacji wysiłków w dziedzinie badań i rozwoju, obejmujące instytucje wspólnotowe oraz przedsiębiorstwa europejskie, podejmowano już w latach 70. XX wieku. Ich pierwszym konkretnym efektem było utworzenie w 1983 r. Europejskiego Programu Strategicznego w Dziedzinie Badań Technologii Informatycznych (European Strategic Programme for Research in Information Technologies, ESPRIT). Obejmował on wybrane zintegrowane projekty badawcze poświęcone technologiom informatycznym oraz transferowi technologii przemysłowych.

Jego bezpośrednim następcą był pierwszy program ramowy w dziedzinie badań naukowych (Framework Programme for Research and Technological Development, FP) uruchomiony w 1984 r. Był on poświęcony badaniom w dziedzinie biotechnologii, telekomunikacji i technologii przemysłowych. Systematycznie rozszerzane w następnych latach kolejne programy ramowe stały się zasadniczym wspólnotowym instrumentem finansowania badań naukowych. Od początku istnienia tych programów finansowanie unijne skierowane jest nie do państw członkowskich, ale bezpośrednio do podmiotów realizujących zadania badawcze. Nie ma przy tym znaczenia,

22 Komunikat Komisji do Parlamentu Europejskiego, Rady, Europejskiego Komitetu Ekonomiczno-Społecznego oraz Komitetu Regionów: Odnowiony europejski program na rzecz badań i innowacji - szansa Europy na ukształtowanie własnej przyszłości, COM(2018) 306 final z 15 maja 2018 r. 
Tabela 1. Budżet programów ramowych (w mld euro)

\begin{tabular}{|c|c|c|c|}
\hline Nazwa & Okres finansowania & $\begin{array}{c}\text { Budżet dla } \\
\text { wskazanego okresu } \\
\text { finansowania }\end{array}$ & $\begin{array}{c}\text { Budżet w przeliczeniu } \\
\text { na jeden rok trwania } \\
\text { programu }\end{array}$ \\
\hline Pierwszy program ramowy & 1984-1987 & 3,75 & 0,94 \\
\hline Drugi program ramowy & 1987-1991 & 5,40 & 1,35 \\
\hline Trzeci program ramowy & 1990-1994 & 6,60 & 1,65 \\
\hline Czwarty program ramowy & 1994-1998 & 13,22 & 3,31 \\
\hline Piąty program ramowy & $1998-2002$ & 14,96 & 3,74 \\
\hline Szósty program ramowy & $2002-2006$ & 17,88 & 4,47 \\
\hline Siódmy program ramowyb & $2007-2013$ & 53,22 & 7,60 \\
\hline „Horyzont 2020” & $2014-2020$ & 75,92 & 10,85 \\
\hline „Horyzont Europa” & $2021-2027$ & 100 & 14,29 \\
\hline
\end{tabular}

Uwagi:

a Począwszy od czwartego programu ramowego budżet na badania i rozwój został rozbudowany o obszar energii atomowej z odrębnym, przyjmowanym równolegle, budżetem na prace badawczo-rozwojowe i szkolenia. Kwoty w tabeli obejmują oba komponenty.

b Począwszy od siódmego programu ramowego budżet planowany jest na okresy 7-letnie.

Źródło: na podstawie komunikatów i dokumentów z różnych lat z oficjalnej strony Komisji Europejskiej poświęconej badaniom naukowym: https://cordis.europa.eu [dostęp: 25 listopada 2019 r.] oraz https://ec.europa. eu/info/research-and-innovation_en [dostęp: 25 listopada 2019 r.]. Ostateczny budżet programu „Horyzont Europa" zależy od przyjęcia budżetu ogólnego Unii Europejskiej na lata 2021-2027, wskazana w tabeli kwota została zaplanowana w propozycji Komisji Europejskiej z czerwca 2018 r. (https://ec.europa.eu/commission/ presscorner/detail/en/IP_18_4041 [dostęp: 25 listopada 2019 r.]).

czy podmioty te mają charakter publiczny, czy prywatny, czy są ośrodkami badawczymi, czy też przedsiębiorstwami prowadzącymi działalność innowacyjną.

W latach 1984-2020 zrealizowano w sumie osiem programów ramowych (ostatni z nich pod nazwą „Horyzont 2020"), a przeznaczone na nie środki były systematycznie zwiększane (tabela 1). Szczególnie istotny skok nastąpił w siódmym programie ramowym (FP7). Wprawdzie od tego programu wydłużony został okres finansowania z pięciu do siedmiu lat, lecz pula środków przypadających średnio na jeden rok przeliczeniowy także uległa istotnemu zwiększeniu. Ten trend stałego wyraźnego podwyższania budżetu przeznaczonego na działalność badawczo-rozwojową i innowacyjną utrzymał się w kolejnych okresach finansowania. Budżet trwającego obecnie programu „Horyzont 2020" jest o ponad 40\% wyższy niż FP7, aczkolwiek zwiększony został także jego zakres merytoryczny (szerzej na temat tego programu w dalszej części artykułu). Co ważne, jednocześnie rośnie udział wydatków na badania i innowacje w całym budżecie UE: od 5-6\% w latach 2000-2007 do ponad 8\% po 2016 r., choć nadal ten wzrost jest bardzo wolny ${ }^{23}$.

23 Europe - the Global Centre for Excellent Research, Study requested by the ITRE committee, European Parliament, April 2019, s. 44. 
Propozycja Komisji Europejskiej na nadchodzącą perspektywę finansową (2021-2027) opiewa już na 100 mld euro, z czego 97,6 mld euro zaplanowano na rzecz programu „Horyzont Europa” (w tym 3,5 mld euro zostanie przydzielone w ramach funduszu InvestEU), a 2,7 mld euro zaplanowano na program badawczo-szkoleniowy Euroatomu ${ }^{24}$. Uruchomienie tych środków wymaga oczywiście wcześniejszego osiągnięcia porozumienia w sprawie ogólnego długoterminowego budżetu UE i powiązanych wniosków sektorowych. Wstępne porozumienie polityczne w tej sprawie zostało osiągnięte przez Parlament Europejski, Radę i Komisję w marcu 2019 r. $^{25}$, lecz musi ono zostać jeszcze formalnie zatwierdzone przez nowo wybrany Parlament Europejski oraz Radę.

Jak wcześniej wspomniano, decyzje dotyczące finansowania projektów badawczo-rozwojowych - w przeciwieństwie do projektów finansowanych np. z funduszy strukturalnych - podejmowane są na poziomie europejskim. Do podstawowych zasad rządzących rozdysponowaniem środków należą również:

- projektowy charakter dystrybucji środków - budżet nie jest dzielony na strategie czy inicjatywy krajowe bądź też kierowany na subsydiowanie instytucji badawczych, lecz przeznaczany na realizację konkretnych projektów,

- $\quad$ współpraca międzynarodowa - preferowane są projekty realizowane przez konsorcja złożone z kilku (kilkunastu) partnerów (instytucji) z różnych państw,

- konkursowy wybór projektów - dofinansowywane projekty są wybierane w ogłaszanych przez Komisję Europejską konkursach na podstawie oceny dokonywanej przez grupę niezależnych ekspertów,

- zgodność z kierunkami polityki badawczo-rozwojowej i wymogami Unii Europejskiej - zgłaszane projekty muszą odpowiadać priorytetom wskazanym w odpowiednim programie ramowym oraz uwzględniać wkład własny,

- wsparcie działań niemożliwych do realizacji na poziomie krajowym - projekty muszą mieć wymiar europejski, a nie tylko lokalny.

\section{Realizacja programu „Horyzont 2020”}

Program „Horyzont 2020" jest już ósmym programem ramowym ${ }^{26}$, lecz o znacznie rozszerzonym zakresie w stosunku do poprzednich programów finansowania badań naukowych. Objęte nim zostały trzy, dotychczas odrębne, działania - poza finansowaniem badań i rozwoju technologicznego, co dotychczas było jedyną domeną programów ramowych - także projekty na rzecz innowacyjności (w latach 2007-2013 część programu ramowego na rzecz konkurencyjności

24 Budżet UE: Komisja proponuje najbardziej ambitny w historii program z dziedziny badań i innowacji, komunikat prasowy z 7 czerwca 2018 r., https://ec.europa.eu/commission/presscorner/detail/pl/IP_18_4041 [dostęp: 25 listopada 2019 r.].

25 Budżet UE na lata 2021-2027: Komisja z zadowoleniem przyjmuje wstępne porozumienie w sprawie programu "Horyzont Europa", przyszłego unijnego programu wzakresie badań naukowych i innowacji, komunikat prasowy z 20 marca 2019 r., https://ec.europa.eu/commission/presscorner/detail/pl/IP_19_1676 [dostęp: 25 listopada 2019 r.].

26 Rozporządzenie Parlamentu Europejskiego i Rady (UE) nr 1291/2013 z 11 grudnia 2013 r. ustanawiające "Horyzont 2020" - program ramowy w zakresie badań naukowych i innowacji (2014-2020) oraz uchylające decyzję nr 1982/2006/WE, Dz.Urz. UE L 347 z 20 grudnia 2013 r. 
i innowacji ${ }^{27}$ ) oraz działalność Europejskiego Instytutu Innowacji i Technologii (European Institute of Innovation and Technology, EIT) ${ }^{28}$. Co do zasady, z budżetu programu "Horyzont 2020" mogły być finansowane badania podstawowe, przemysłowe, prace rozwojowe, jak również faza demonstracyjna i komercjalizacyjna opracowanego rozwiązania. Przy czym na projekty innowacyjne można było uzyskać dofinansowanie w wysokości 70\% kosztów kwalifikowanych, a w przypadku projektów badawczych - $100 \%$.

Program został podzielony na trzy kluczowe filary zdefiniowane jako: (1) „Doskonała nauka” (Excellent Science), (2) „Przywództwo przemysłowe” (Industrial Leadership), (3) „Wyzwania społeczne" (Societal Challenges), z budżetami wynoszącymi odpowiednio 24,4 mld euro, 17 mld euro i 29,7 mld euro. Każdy z tych filarów został dodatkowo podzielony na poszczególne priorytety, także z wyodrębnionym budżetem, np. na działania programu Maria Skłodowska-Curie w filarze „Doskonała nauka” przeznaczono 6,1 mld euro, a w filarze „Przywództwo przemysłowe” przewidziano 0,6 mld euro na projekty dotyczące innowacyjności w małych i średnich przedsiębiorstwach. Najbardziej rozbudowany filar trzeci objął siedem priorytetów: zdrowie (7,5 mld euro), żywność (3,9 mld euro), energia (6 mld euro), transport (6,3 mld euro), klimat (3 mld euro), włączające społeczeństwo (1,3 mld euro) i bezpieczeństwo (1,7 mld euro) $)^{29}$. Ponadto odrębną pulę środków przewidziano na działania o charakterze horyzontalnym: „Upowszechnianie doskonałości i poszerzanie uczestnictwa” z budżetem w wysokości 0,8 mld euro oraz "Nauka z udziałem i dla społeczeństwa" z budżetem w wysokości 0,5 mld euro, a także na działalność Wspólnego Centrum Badawczego (Voint Research Centre, JRC) niezwiązaną z energią jądrową (1,9 mld euro), badania realizowane przez Europejski Instytut Innowacji i Technologii (2,7 mld euro), oraz prace badawcze w obszarze energii atomowej (1,6 mld euro) ${ }^{30}$.

Wprowadzając kolejną edycję programu finansowania badań naukowych, Komisja Europejska podjęła próbę uproszczenia zasad regulujących przyznawanie dotacji przez ograniczenie liczby programów, ujednolicenie stosowanych reguł i zharmonizowanie procesów zarządzania dotacjami oraz usprawnienie powiązanych systemów informatycznych, skrócenie czasu oczekiwania na przyznanie dotacji i dokonanie płatności. Istotnym elementem przyczyniającym się

27 CIP - Competitiveness and Innovation Framework Programme, powołany decyzją nr 1639/2006/WE Parlamentu Europejskiego i Rady z 24 października 2006 r. ustanawiającą Program ramowy na rzecz konkurencyjności i innowacji (2007-2013), Dz.Urz. UE L 310 z 9 listopada 2006 r. W kolejnej perspektywie finansowej program ten został ograniczony do wspierania konkurencyjności przedsiębiorstw jako COSME - Programme for the Competitiveness of Enterprises and small and medium-sized enterprises, dla którego podstawą prawną jest rozporządzenie Parlamentu Europejskiego i Rady (UE) nr 1287/2013 z 11 grudnia 2013 r. ustanawiające program na rzecz konkurencyjności przedsiębiorstw oraz małych i średnich przedsiębiorstw (COSME) (2014-2020) i uchylające decyzję nr 1639/2006/WE, Dz.Urz. UE L 347 z 20 grudnia 2013 r.

28 Europejski Instytut Innowacji i Technologii powołany w 2008 r. rozporządzeniem Parlamentu Europejskiego i Rady (WE) nr 294/2008 z 11 marca 2008 r., Dz.Urz. UE L 97 z 9 kwietnia 2008 r.

29 CERN, EU Projects Office, http://cerneu.web.cern.ch/horizon2020/structure [dostęp: 5 grudnia 2019 r.]; za: M. Pawlak, Program Unii Europejskiej HORYZONT 2020 dla małych i średnich przedsiębiorstw, Politechnika Lubelska, Lublin 2016, s. 24.

30 Analiza wykorzystania przez polskich beneficjentów środków w ramach programów zarządzanych centralnie przez Komisję Europejska: Horyzont 2020. Raport końcowy dla Ministerstwa Inwestycji i Rozwoju, Ecorys Polska Sp. z o.o., Warszawa, październik-grudzień 2017 r. 
do uproszczenia były nowe struktury organizacyjne i horyzontalne, zwłaszcza nowo utworzone Wspólne Centrum Wsparcia (Common Support Centre, CSC), które ogniskowało działania związane z udzielaniem, rozliczaniem i audytem grantów. Doprowadziło to do poprawy spójności we wdrażaniu programu. Jednak, według oceny Europejskiego Trybunału Obrachunkowego (ETO), nie wszystkie działania przyniosły pożądane rezultaty i nadal istnieją możliwości poprawy. Trybunał wskazał w szczególności takie mankamenty, jak ${ }^{31}$ :

- nie w pełni wykorzystane możliwości ograniczenia obciążeń administracyjnych, w tym niska skuteczność tzw. pieczęci doskonałości, która miała pomóc w uzyskaniu finansowania z innych źródeł na rzecz najlepszych niewybranych wniosków,

- nadal skomplikowane zasady rozliczania kosztów osobowych prowadzące do błędów w zestawieniach poniesionych wydatków, przy czym kolejne modyfikacje prowadziły do nieporozumień i braku pewności prawa,

- różna jakość audytów prowadzonych przez firmy zewnętrzne, co bywa źródłem frustracji i nieporozumień wśród beneficjentów, choć dzięki nowej strategii zmalały obciążenia związane $z$ audytami.

Istotną rolę we wdrażaniu programów ramowych odgrywają krajowe punkty kontaktowe. Sieć krajowych punktów kontaktowych stanowi ważny kanał komunikacji między Komisją a beneficjentami, a ich wsparcie jest szczególnie istotne dla nowych podmiotów, a zwłaszcza małych i średnich przedsiębiorstw, które nie mają wystarczających kompetencji w przygotowywaniu wniosków. Trybunał wskazał jednak na istotne różnice w poziomie wsparcia technicznego, jaki zapewniają krajowe punkty kontaktowe w poszczególnych państwach członkowskich (w ankiecie zrealizowanej przez ETO poziom niezadowolenia z jakości usług wynosił od 4 do 25\%)

Ocena funkcjonowania programu przeprowadzona przez Komisję Europejską pokazała z kolei, że zainteresowanie wsparciem finansowym na działalność badawczo-rozwojową i innowacyjną wyraźnie rośnie. Do końca 2016 r., a więc tylko w ciągu pierwszych trzech lat, złożono ponad 100 tys. wniosków, co oznacza wzrost średniorocznie o 65\% w porównaniu z poprzednim programem (FP7). Większość projektów (ok. 75\% całości dofinansowania) realizowanych jest przez konsorcja wielonarodowe, także z udziałem państw spoza Unii Europejskiej, choć przeważająca część środków (ponad 90\%) trafia do podmiotów z państw członkowskich Unii³.

Warta uwagi jest wyraźna dysproporcja między tzw. nowymi (UE-13) a starymi (UE-15) państwami członkowskimi Unii. Według danych na 1 lipca 2018 r. podmioty z UE-15 składają średnio po 6,5 wniosku grantowego, podczas gdy na jeden podmiot UE-13 przypada 3,8 wniosku.

31 Większość działań na rzecz uproszczenia podjętych w zwiqzzu z programem "Horyzont 2020" przysłużłła się beneficjentom, lecz nadal istnieja możliwości poprawy, Europejski Trybunał Obrachunkowy, sprawozdanie specjalne, nr 28/2018, s. 8-10, https://www.eca.europa.eu/pl/Pages/Docitem.aspx?did=47542 [dostęp: 5 grudnia 2019 r.].

32 Ibidem, s. 26-27.

33 Key findings from the Horizon 2020 interim evaluation, Directorate-General for Research and Innovation, European Commission, 2017, s. 6, https://ec.europa.eu/research/evaluations/pdf/brochure_interim_evaluation_horizon_2020_key_findings.pdf [dostęp: 5 grudnia 2019 r.]. 


\section{Wykres 1. Porównanie środków z programów „Horyzont 2020” i FP7 uzyskanych rocznie przez podmioty z poszczególnych państw wg stanu na na dzień 1 lipca 2018 r. (w mln euro)}

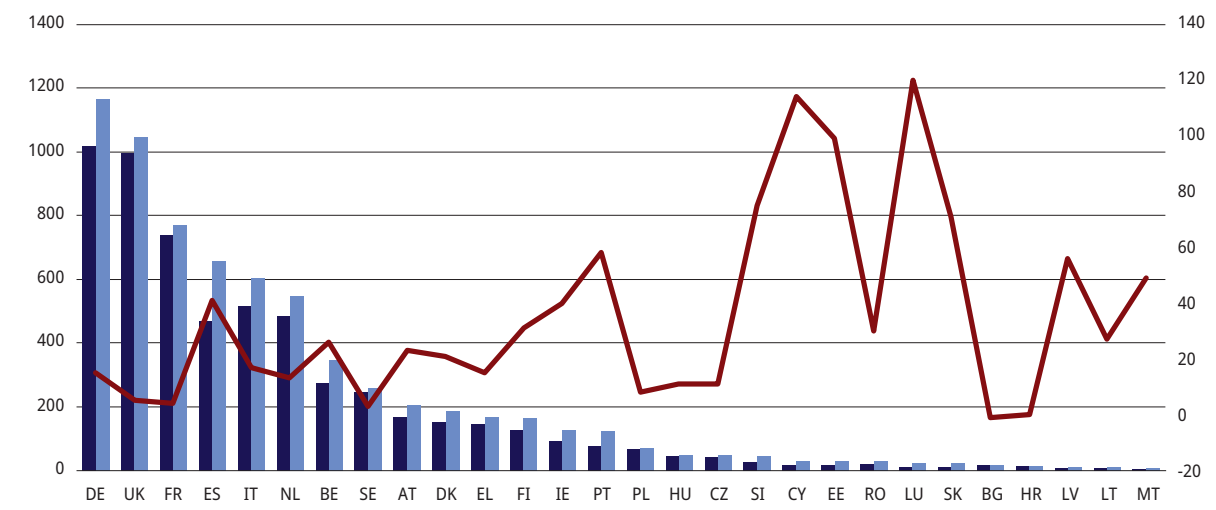

\begin{tabular}{llllllllllllllllllllllllllll} 
FP7 1022 & 1003 & 744 & 471 & 519 & 489 & 277 & 250 & 170 & 154 & 146 & 125 & 90 & 75 & 63 & 41 & 41 & 24 & 13 & 14 & 19 & 9 & 11 & 14 & 13 & 7 & 7 & 3 \\
\hline
\end{tabular}

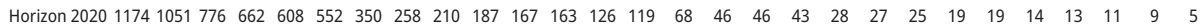

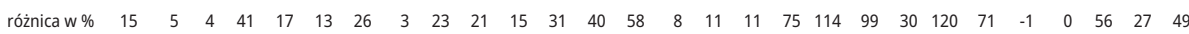

Oznaczenia: AT - Austria, BE - Belgia, BG - Bułgaria, CY - Cypr, CZ - Czechy, DE - Niemcy, DK - Dania, EE Estonia, EL - Grecja, ES - Hiszpania, FI - Finlandia, FR - Francja, HR - Chorwacja, HU - Węgry, IE - Irlandia, IT - Włochy, LT - Litwa, LU - Luksemburg, LV - Łotwa, MT - Malta, NL - Holandia, PL - Polska, PT - Portugalia, RO - Rumunia, UK - Wielka Brytania, SE - Szwecja, SI - Słowenia, SK - Słowacja.

Źródło: From Horizon 2020 to Horizon Europe. Monitoring Flash No 1.2 Country Participation, European Commission, August 2018, s. 6.

Szczególnie niekorzystnie wypada w tych statystykach Polska. Polscy naukowcy i inżynierowie wydają się wyjątkowo pasywni na tle Unii Europejskiej - na jednego z nich przypada średnio 8,5 aplikacji w porównaniu z 27 przeciętnie dla całej UE. W efekcie ponad połowa środków z „Horyzontu 2020" trafiła do zaledwie pięciu państw: Wielkiej Brytanii, Włoch, Niemiec, Hiszpanii i Francjii ${ }^{34}$. Z drugiej strony państwa te przodują także pod względem własnych wydatków na badania i rozwój, odpowiadając za ponad 70\% inwestycji B+R realizowanych w Unii35.

Udział UE-13 w unijnych programach badawczo-rozwojowych rośnie bardzo powoli. W ciągu pierwszych 4,5 lat trwania programu „Horyzont 2020” cała ta grupa otrzymała 4,8\% wypłaconych środków w porównaniu z 4,2\% otrzymanych w siódmym programie ramowym ${ }^{36}$. W podziale na poszczególne państwa zmiany te są jednak zróżnicowane (wykres 1). Biorąc pod uwagę ogólny wzrost budżetu programu, podmioty ze wszystkich państw członkowskich UE otrzymały wyższą kwotę w przeliczeniu na jeden rok. Wyjątkiem są jedynie Bułgaria (-2\%)

34 From Horizon 2020 to Horizon Europe " "Monitoring Flash" No 1.1. Country Participation, European Commission, August 2018, s. 1-2.

35 Ibidem, s. 4.

36 Ibidem, s. 1. 
i Chorwacja (bez zmian). Największe przyrosty względne odnotowały Luksemburg (120\%), Cypr (114\%), Estonia (99\%) i Słowenia (75\%). Wzrosty te liczone były jednak od niskiej podstawy, zatem w badanym okresie największymi beneficjentami zwiększonego budżetu w wartościach bezwzględnych okazały się podmioty zlokalizowane w Hiszpanii (191 mln euro, wzrost o 41\%), Niemczech (152 mln euro, wzrost o 15\%), Włoszech (89 mln euro, wzrost o 17\%), Belgii (73 mln euro, wzrost o 26\%) i Holandii (64 mln euro, wzrost o 13\%).

Średnioroczna wartość środków uzyskiwanych przez Polskę w programie "Horyzont 2020" w porównaniu z FP7 zwiększyła się zaledwie o 8\%, znacznie mniej zatem niż w wiodących państwach zarówno UE-13, jak i UE-15. Zwiększenie skali wykorzystania środków przez Polskę jest przy tym pięciokrotnie mniejsze niż wzrost samego budżetu unijnego przeznaczonego na badania i rozwój ${ }^{37}$. Do grudnia 2019 r. środki uzyskane przez Polskę w ramach „Horyzontu 2020" wyniosły 477,1 mln euro, co stanowi zaledwie 1\% kwoty wypłaconej łącznie w tym programie ${ }^{38}$. Polska odnotowuje wskaźnik sukcesu uczestnictwa w programie (liczba uczestników zaakceptowanych w stosunku do aplikujących) na poziomie 14,1\%. Gorszy wynik uzyskały jedynie Bułgaria (12,7\%), Węgry (12,3\%) i Litwa (14,06\%), przy średniej dla UE-28 wynoszącej 16,8\% oraz 18-21\% w przypadku najbardziej skutecznych państw (m.in. Francja, Belgia, Austria) ${ }^{39}$.

Najwyższe dofinansowanie netto z tytułu „Horyzont 2020” Polska uzyskała w obszarze technologii informatycznych i telekomunikacyjnych (ponad $61 \mathrm{mln}$ euro), który jest częścią filaru „Przywództwo przemysłowe” oraz w działaniu Maria Skłodowska-Curie (52,8 mln euro), które służy poprawie mobilności międzynarodowej pracowników naukowych na wszystkich etapach kariery, głównie przez granty na badania prowadzone w innych ośrodkach lub finansowanie wspólnych projektów. Najmniejszy udział polskie instytucje odnotowały w działaniu horyzontalnym „Nauka z udziałem i dla społeczeństwa”, w którym łączne dofinansowanie netto dla wszystkich obszarów nie przekroczyło 5,7 mln euro ${ }^{40}$.

\section{Perspektywa finansowa 2021-2027}

W nadchodzącej perspektywie finansowej program finansowania badań naukowych „Horyzont Europa"41 ma mieć budżet o ponad 30\% większy niż kończący się obecnie program „Europa 2020". Jak wyżej wspomniano ${ }^{42}$, zgodnie ze wstępnym porozumieniem Parlamentu, Rady i Komisji z marca 2019 r. został on zaplanowany w wysokości 100 mld euro. Ostateczna wysokość

37 Budżet programu „Horyzont 2020” jest o ok. 40\% większy w porównaniu z siódmym programem ramowym zob. tabela 1

38 Baza danych CORDIS, https://webgate.ec.europa.eu/dashboard [dostęp: 10 grudnia 2019 r.].

39 Dane na koniec września 2018 r., zob. Polska w PR Horyzont 2020, Krajowy Punkt Kontaktowy, http://www. kpk.gov.pl/?p=46240 [dostęp: 10 grudnia 2019 r.].

40 Ibidem.

41 Wniosek rozporządzenie Parlamentu Europejskiego i Rady ustanawiające program ramowy w zakresie badań naukowych i innowacji „Horyzont Europa” oraz zasady uczestnictwa i upowszechniania obowiązujące w tym programie, COM(2018) 435 final.

42 Budżet UE na lata 2021-2027: Komisja z zadowoleniem, op. cit. 
tych środków zależy od uzgodnień dotyczących całej perspektywy finansowej 2021-2017, która nadal jest w trakcie negocjacji.

Program - jak poprzednio - ma wspierać się na trzech głównych filarach. Zostały one nazwane następująco ${ }^{43}$ : (1) „Doskonała nauka” (Excellent Science), (2) „Wyzwania globalne i europejska konkurencyjność przemysłowa" (Global Challenges and European Industrial Competitiveness), (3) „Innowacyjna Europa” (Innovative Europe). Wstępnie Komisja Europejska zaproponowała następujący podział środków na każdy z filarów: (1) 25,8 mld euro; (2) 52,7 mld euro; (3) 13,5 mld euro. Ich uzupełnieniem będą dwa działania horyzontalne o wspólnej nazwie „Poszerzanie udziału i wzmacnianie europejskiej przestrzeni badawczej" (Widening Participation and Strengthening European Research Area), dla których proponuje się budżet w wysokości 2,1 mld euro. Ponadto 2,4 mld euro ma kosztować program badawczo-szkoleniowy Euroatomu, a 3,5 mld euro ma wynieść koperta funduszu InvestEU.

Uwaga Komisji Europejskiej koncentruje się obecnie na drugim filarze, który ma być odpowiedzią na najważniejsze wyzwania, przed jakimi stoi Europa w najbliższej przyszłości. Zdefiniowano w nim sześć tzw. klastrów, czyli priorytetowych obszarów badawczych. Są to:

- zdrowie (Health),

- kultura, kreatywność i społeczeństwo włączające (Culture, Creativity and Inclusive Society),

- bezpieczeństwo obywatelskie dla społeczeństwa (Civil Security for Society),

- cyfryzacja, przemysł i przestrzeń kosmiczna (Digital, Industry and Space),

- klimat, energia i mobilność (Climate, Energy and Mobility),

- żywność, biogospodarka, zasoby naturalne, rolnictwo i środowisko (Food, Bioeconomy, Natural Resources, Agriculture and Environment $)^{44}$.

Jak więc widać, następuje wyraźne przeorientowanie kierunków badawczych na kwestie społeczne, jako że wobec narastającej złożoności i tempa przemian współczesnego świata narastają obawy obywateli o kwestie bezpieczeństwa i ich własną przyszłość w zmieniającym się społeczeństwie. Na przykład rozwój technologiczny, szczególnie w zakresie robotyki i cyfryzacji,

43 Terminologia oraz poszczególne kwoty pochodzą ze zmodyfikowanej w stosunku do projektu rozporządzenia prezentacji programu opublikowanym przez Komisję w maju 2019 r. w dokumencie: Horizon Europe. The Next EU Research \& Innovation Investment Programme (2021-2027). Based on the Commission Proposal for Horizon Europe, the common understanding between co-legis/ators and the Partial General Approach, both approved in April 2019, European Commission, May 2019, s. 11, https://ec.europa.eu/info/sites/info/files/ research_and_innovation/ec_rtd_he-presentation_062019_en.pdf [dostęp: 7 stycznia 2020 r.]. W projekcie rozporządzenia nazwy filarów brzmiały następująco: „Otwarta nauka” (Open science), "Globalne wyzwania i konkurencyjność przemysłowa” (Global Challenges and Industrial Competitiveness), "Otwarte innowacje” (Open Innovation).

44 Orientations towards the first Strategic Plan for Horizon Europe, European Commission, October 2019, s. 2, https://ec.europa.eu/info/files/co-design-towards-first-strategic-plan-horizon-europe_en [dostęp: 7 stycznia 2020 r.]. Publikacja ta zawiera także szerokie omówienie każdego z klastrów, wskazując na: globalne wyzwania z nim związane, cele polityki UE w tym obszarze, zakładane rezultaty, kierunki oczekiwanych badań i innowacji, zakres współpracy międzynarodowej oraz potencjalnych partnerstw europejskich, jak również misję, której każdy klaster może dotyczyć (aneksy 1-6, s. 29-131). 
najprawdopodobniej będzie wymagał zdobycia nowych umiejętności i może budzić uzasadnione obawy dotyczące wpływu na szanse zatrudnienia. Zwiększona mobilność transgraniczna powoduje z kolei obawy dotyczące zarządzania granicami zewnętrznymi Unii i bezpieczeństwa europejskiego. Narastają także tendencje do kwestionowania podstawowych zasad poszanowania praw człowieka, demokracji i praworządności oraz utraty zaufania do instytucji ustanowionych w Unii Europejskiej. Zdaniem Komisji Europejskiej istotne staje się zatem skoncentrowanie się na potrzebach i niepokojach ludzi, których te zjawiska dotykają.

Pozostałe dwa filary są w większym stopniu kontynuacją dotychczasowej polityki finansowania sfery badawczo-naukowej Unii Europejskiej. Filar „Doskonała nauka” obejmuje działanie Maria Skłodowska-Curie zorientowane na wymianę naukową, prace Europejskiej Rady ds. Badań Naukowych oraz finansowanie infrastruktury badawczej. W filarze „Innowacyjna Europa” ujęto działalność Europejskiego Instytutu Innowacji i Technologii, Europejskiej Rady ds. Innowacji (European Innovation Council, EIC) - nowego podmiotu mającego na celu wspieranie innowacji wysokiego ryzyka ${ }^{45}$ oraz rozmaitych aktywności służących zintegrowaniu działań innowacyjnych w skali europejskiej, a także wzmacnianiu synergii między środowiskiem akademickim, przedsiębiorcami (zwłaszcza małych i średnich przedsiębiorców) i operatorami rynku. Działania horyzontalne mają skupiać się na wzmacnianiu sieci naukowych, wspieraniu rozwoju kariery naukowców na wszystkich jej etapach, przyciąganiu wysokiej jakości kadr w organizacjach badawczych, budowaniu synergii ze szkolnictwem wyższym itp. Najważniejszymi celami ogólnymi jest wspieranie otwartej nauki, innowacyjnych praktyk przedsiębiorczych czy wzmacnianie zasady uczenia się przez całe życie.

Nowym narzędziem wdrażania programu będą tzw. misje, które mają wprowadzić mechanizm lepszego dostosowania inicjatyw badawczych do potrzeb społecznych (demand-driven research). Według Komisji: [m]isja to szereg działań w różnych dyscyplinach, majacych na celu osiągnięcie śmiałego, inspirującego i mierzalnego celu w ustalonym czasie, mającego wpływ na społeczeństwo i kształtowanie polityki, a także istotnego dla znacznej części populacji europejskiej i szerokiego grona obywateli Europy ${ }^{46}$. Wstępnie Komisja wskazała pięć obszarów, w których misje będą definiowane: dostosowanie do zmian klimatycznych; nowotwory; zdrowe oceany, morza, wody przybrzeżne i śródlądowe; neutralne klimatycznie i inteligentne miasta; zdrowa gleba i żywnośćc ${ }^{47}$.

Wszystkie te zmiany mają służyć skuteczniejszemu promowaniu przełomowych rynkowych innowacji, bardziej strategicznemu i elastycznemu podejściu do zarządzania programem oraz wzmocnieniu synergii z innymi programami Unii Europejskiej. Załącznik do rozporządzenia

45 Europejska Rada ds. Innowacji ma za zadanie wypełnienie luki w finansowaniu innowacyjnych przedsiębiorstw podejmujących innowacje o szczególnie wysokim ryzyku technologicznym i rynkowym. Pierwsza faza pilotażowa została uruchomiona przez Komisję Europejską w 2017 r. W marcu 2019 r. uruchomiony został pogłębiony pilotaż, a w czerwcu 2019 r. powołano Radę Doradczą ds. Pilotażu EIC. Oczekuje się, że ta struktura przejściowa będzie trwała do 2021 r., kiedy to przewiduje się powołanie formalnej rady EIC w ramach „Horyzont Europa”, https://ec.europa.eu/info/files/european-innovation-council-eic_en [dostęp: 7 stycznia 2020 r.].

46 Horizon Europe. The Next EU Research \& Innovation Investment Programme, op. cit., s. 15.

47 Ibidem, s. 16. 
ustanawiającego program ${ }^{48}$ wymienia aż 16 programów, z którymi ma być osiągnięta synergia, począwszy od funduszy rolnych przez fundusz rozwoju regionalnego i fundusz społeczny, a skończywszy na Europejskim Funduszu Obronnym. Jest to pierwszy program wspierania badań i rozwoju, w którym konieczność synergii została tak jasno podkreślona wraz ze wskazaniem konkretnych działań, gdzie ma mieć zastosowanie. Dla przykładu, w przypadku - wydawałoby się nieoczywistego - Instrumentu Sąsiedztwa, Rozwoju i Współpracy Międzynarodowej synergia ma zapewnić spójność i unikanie powielania badań naukowych realizowanych z udziałem państw trzecich oraz działań w zakresie absorpcji rynkowej i budowania zdolności wdrażanych w ramach wspomnianego instrumentu. Pomóc ma w tym uzgodniona definicja potrzeb i obszarów interwencji sformułowana wspólnie w trakcie procesu planowania strategicznego.

\section{Wnioski dla Polski}

Niski jak dotychczas udział Polski w unijnych programach grantowych na tle średniej unijnej przekłada się na podstawowe wskaźniki używane jako mierniki efektywności w działalności naukowo-badawczej. W takich kategoriach, jak: liczba cytowań w prestiżowych wydawnictwach międzynarodowych, zakres współautorstwa w międzynarodowych publikacjach, liczba patentów czy poziom zatrudnienia w dziedzinach wymagających wiedzy, Polska także nie dorównuje przeciętnemu poziomowi odnotowywanemu dla UE-28 (tabela 2).

W badaniach na temat wykorzystania przez polskich beneficjentów środków dostępnych w programie "Horyzont 2020", zrealizowanych w 2017 r. na zlecenie Ministerstwa Inwestycji i Rozwoju ${ }^{49}$, wskazuje się, że polscy wnioskodawcy charakteryzują się niską innowacyjnością prowadzonych działań oraz składanych wniosków, a jednocześnie mają relatywnie słabą zdolność do tworzenia konsorcjów, ograniczając się często do bycia partnerem w projekcie. Stanowi to nie najlepszy punkt wyjścia do nowego programu, w którym szczególnie duży nacisk kładziony jest właśnie na nowatorstwo projektów oraz zdolność budowania sieci współpracy.

W tym kontekście istotne jest wzmacnianie mobilności polskich naukowców, dzięki której nie tylko tworzone są podstawy przyszłego budowania partnerstw w świecie nauki, ale także pojawia się możliwość zdobycia doświadczenia wykraczającego poza własne środowisko, zetknięcia z niestandardowymi sposobami rozwiązywania problemów czy prowadzenia prac badawczych, otwarcia na perspektywiczne aspekty realizowanych badań itp. Wsparciem dla mobilności ma być nowa instytucja powołana w 2017 r. - Narodowa Agencja Wymiany Akademickiej (NAWA) ${ }^{50}$, która zastąpiła Biuro Uznawalności Wykształcenia i Wymiany Międzynarodowej. W założeniu ma ona dopełnić system tworzony przez dwie inne agencje: Narodowe Centrum Nauki oraz Narodowe Centrum Badań i Rozwoju, a w przyszłości będzie również mogła zostać operatorem środków unijnych.

Jednym z kierunków działań Agencji mają być - z jednej strony - trwające do dwóch lat programy wyjazdowe dla polskich pracowników naukowo-dydaktycznych, co pomoże im włą-

48 Zob. przypis 26.

49 Analiza wykorzystania przez polskich beneficjentów środków, op. cit., s. 5.

50 Ustawa z 7 lipca 2017 r. o Narodowej Agencji Wymiany Akademickiej, t.j. Dz.U. 2019, poz. 1582. 
Tabela 2. Wybrane mierniki efektywności naukowo-badawczej Polski na tle Unii Europejskiej

\begin{tabular}{|c|c|c|c|c|}
\hline Rodzaj wskaźnika & Polska & $\begin{array}{c}\text { Średnia dla } \\
\text { UE-28 }\end{array}$ & $\begin{array}{l}\text { Państwo } \\
\text { o najwyższym } \\
\text { wskaźniku } \\
\text { i wartość } \\
\text { wskaźnika }\end{array}$ & $\begin{array}{c}\text { Państwo } \\
\text { o najniższym } \\
\text { wskaźniku } \\
\text { i wartość } \\
\text { wskaźnika }\end{array}$ \\
\hline $\begin{array}{l}\text { Udział w grantach przyzna- } \\
\text { nych w programie „Horyzont } \\
2020 \text { " na tysiąc naukowców } \\
\text { i inżynierów w kraju, na dzień } \\
1 \text { lipca } 2018 \text { r. }\end{array}$ & 1,1 & n.a. & $\begin{array}{l}\text { Cypr } \\
15,5\end{array}$ & $\begin{array}{c}\text { Polska } \\
1,1\end{array}$ \\
\hline $\begin{array}{l}\text { Udział w } 10 \% \text { najczęściej } \\
\text { cytowanych publikacji na } \\
\text { świecie, } 2015 \text { r. }\end{array}$ & 5,1 & 10,57 & $\begin{array}{c}\text { Wielka Brytania } \\
\qquad 15,0\end{array}$ & $\begin{array}{c}\text { Bułgaria } \\
4,2\end{array}$ \\
\hline $\begin{array}{l}\text { Współudział w międzynaro- } \\
\text { dowych publikacjach nauko- } \\
\text { wych na milion mieszkańców, } \\
2017 \text { r. }\end{array}$ & 296,6 & 517,45 & $\begin{array}{c}\text { Dania } \\
2345,9\end{array}$ & $\begin{array}{c}\text { Rumunia } \\
181,8\end{array}$ \\
\hline $\begin{array}{l}\text { Międzynarodowe zgłoszenia } \\
\text { patentowe w stosunku do } \\
\text { PKB (w mld, wg parytetu siły } \\
\text { nabywczej), } 2015 \text { r. }\end{array}$ & 0,7 & 3,53 & $\begin{array}{c}\text { Szwecja } \\
9,1\end{array}$ & $\begin{array}{c}\text { Rumunia } \\
0,2\end{array}$ \\
\hline $\begin{array}{l}\text { Zatrudnienie w dziedzinach } \\
\text { wymagających wiedzy jako } \\
\text { odsetek całkowitego zatrud- } \\
\text { nienia, } 2017 \text { r. }\end{array}$ & 10,3 & 14,2 & $\begin{array}{l}\text { Luksemburg } \\
\qquad 22,0\end{array}$ & $\begin{array}{c}\text { Rumunia } \\
7,7\end{array}$ \\
\hline
\end{tabular}

Źródło: From Horizon 2020 to Horizon Europe. Monitoring Flash No 1.2 Country Participation, European Commission, August 2018, s. 9.

czyć się w międzynarodowy obieg nauki, a - z drugiej strony - tworzenie atrakcyjnej oferty dla pracujących za granicą polskich naukowców chcących ponownie prowadzić badania w naszym kraju. Umiędzynarodowieniu polskiej nauki mają służyć też trzy inne rodzaje działań: programy mobilności krótkookresowej (udział w konferencjach, stażach, wizytach studyjnych czy szkoleniach krótkookresowych), programy wspierające umiędzynarodowienie kształcenia (tworzenie i realizacja studiów w partnerstwie z zagranicznymi ośrodkami, stypendia dla zagranicznych doktorantów), wzmocnienie potencjału organizacyjnego i promocja (finansowanie działań służących tworzeniu projakościowego systemu promocji oraz upowszechnianiu wyników badań w obiegu międzynarodowym) ${ }^{51}$. Za wcześnie jeszcze, by ocenić skuteczność tej strategii, lecz wydaje się, że zwłaszcza programy długoterminowej aktywności w ośrodkach zagranicznych polskich naukowców, którzy osiągnęli już pewien etap kariery, jest obiecujący.

Innym mankamentem wskazanym przez wspomniane wyżej badania ${ }^{52}$ jest słabość wizerunkowa Polski jako państwa, w którym prowadzone są prace badawczo-rozwojowe i w którym powstają nowe, przełomowe teorie naukowe oraz ważne wdrożenia. Poniekąd jest to również

51 Narodowa Agencja Wymiany Akademickiej. Zarys strategii na lata 2018-2025, https://nawa.gov.pl/images/ Strategia-NAWA.pdf [dostęp: 7 stycznia 2020 r.].

52 Analiza wykorzystania przez polskich beneficjentów środków, op. cit., s. 74. 
efekt niezadowalającego umiędzynarodowienia polskiej nauki, ale także wynik małego zaangażowania w sam proces programowania, oceny oraz realizacji programów unijnych. Z wywiadów przeprowadzonych na potrzeby omawianego badania wynika, że mała grupa polskich uczelni czy przedsiębiorstw korzysta z możliwości stowarzyszania się w międzynarodowych organizacjach służących jako platformy czynnego oddziaływania na kształt programu, a nieliczni polscy naukowcy angażują się jako eksperci do oceny wniosków składanych w programach unijnych. W efekcie nawet włączenie się do projektu jako partner w konsorcjum budowanym przez bardziej znaczący podmiot wymaga dużego wysiłku ze strony polskich wnioskodawców. W toku badania zidentyfikowano podmioty, które wykazują aktywność na etapie programowania i potwierdzono ich realną skuteczność w konkursach, aczkolwiek są to jednocześnie jednostki o silnej pozycji wynikającej także z innych względów. Zatem z dużym prawdopodobieństwem można stwierdzić, że i tak dobrze poradziłyby sobie w pozyskiwaniu środków na projekty, choć aktywność w strukturach unijnych dodatkowo umacnia ich pozycję.

Zgodnie z założeniami zaradzić temu miała nowa ustawa o szkolnictwie wyższym i nauce (tzw. konstytucja dla nauki) ${ }^{53}$, która w uzasadnieniu wprost wskazuje na niskie umiędzynarodowienie polskiej nauki, przywołując jako przykład wyniki polskich naukowców w konkursach grantowych realizowanych przez Europejską Radę ds. Badań Naukowych (European Research Council, ERC) ${ }^{54}$. Ostatecznie aspekty międzynarodowe działalności naukowej zostały w stosunkowo niewielkim stopniu uwzględnione w przepisach ustawy, np. w rozdziale 3 „Stopień doktora habilitowanego" art. 219 wskazuje na wymóg istotnej aktywności naukowej w więcej niż jednej uczelni lub instytucji, w szczególności zagranicznej, natomiast w myśl art. 242 w ocenie jakości kształcenia należy uwzględnić ogólnie rozumiane umiędzynarodowienie, bez dookreślenia, co ono oznacza. Zmianie ulega również system oceny wyników naukowych, pozwalając na odejście od dużej liczby relatywnie mało znaczących osiągnięć czy publikacji (np. w niskiej jakości periodykach krajowych) na rzecz wysokiej wyceny trudnych, złożonych projektów badawczych. Zmienia się również klasyfikacja dziedzin i dyscyplin naukowych tak, aby była ona dostosowana do standardów zagranicznych.

Jak już zostało wspomniane, jest jeszcze za wcześnie, by oceniać skuteczność nowych przepisów w omawianym zakresie; budzą one przy tym wiele kontrowersji w środowisku naukowym. Ocena tych zmian nie jest przedmiotem niniejszego opracowania. Warto jednak zauważyć, że w pierwszych przymiarkach do programu „Horyzont Europa” udział polskich naukowców jest ponownie poniżej potencjału, jakim dysponuje polska nauka. Świadczą o tym wyniki wyborów do rad misji badawczych nowego programu, które odbyły się w drugiej połowie 2019 r. Do każdej z pięciu misji wybranych zostało 15 członków; ich rolą będzie doradzanie Komisji Europejskiej w identyfikacji kluczowych zagadnień z danego obszaru. W tym gronie znalazło się tylko

53 Ustawa z 20 lipca 2018 r. - Prawo o szkolnictwie wyższym i nauce, Dz.U. poz. 1668.

54 Jak podaje uzasadnienie do rządowego projektu ustawy: W2016 r. W Polsce realizowanych było tylko 6 grantów ERC. Dla porównania: w Hiszpanii (porównywalnej pod względem liczby ludności) - realizowanych było 165 grantów tego typu; w Holandii (porównywalnej pod względem liczby naukowców) - 230 grantów, a na Węgrzech (nowy kraj (złonkowski) - 15 grantów, druk sejmowy nr 2446, uzasadnienie, s. 7, http://www.sejm.gov.pl/Sejm8.nsf/ druk.xsp?nr=2446 [dostęp: 7 stycznia 2020 r.]. 
czworo Polaków 55 , co odpowiada 5,3\% liczby członków rad, podczas gdy stanowimy ponad 7\% ludności UE, a odsetek osób z wyższym wykształceniem (magisterskim) w Polsce wynosi 21\% w porównaniu ze średnią dla 22 państw UE ${ }^{56}$ wynoszącą 13\% $\%^{57}$.

Istotnym aspektem nadchodzącego programu jest wzmacnianie synergii między środowiskiem akademickim i przedsiębiorcami. Niestety, współpraca polskiej nauki z przemysłem jest nadal niewystarczająca mimo trwających od wielu lat prób jej stymulowania. Taka współpraca powinna mobilizować obie sfery do działań innowacyjnych w imię obopólnych korzyści, lecz w Polsce nadal dominuje atmosfera braku zaufania i bariery mentalnościowe utrudniające realizację wspólnych celów.

Przywoływane już kilkukrotnie badania ${ }^{58}$ wskazują na pewne cechy charakterystyczne, wspólne dla wyróżniających się wnioskodawców - wielokrotnych beneficjentów programu „Horyzont 2020". Należą do nich m.in. duży potencjał naukowo-badawczy, multidyscyplinarność, aktywny udział w kształtowaniu wizji rozwoju przemysłu w Europie, pełne pokrycie wszystkich etapów rozwoju produktu, zdolność do współpracy z podmiotami z przemysłu, liczne powiązania i kontakty z podmiotami (projektodawcami) z innych państw.

Uczestnicy konferencji zorganizowanej w listopadzie 2019 r. przez Polską Akademię Nauk ${ }^{59}$ wskazali na jeszcze jeden - jak się wydaje nie mniej istotny niż potencjał naukowy - element, a mianowicie umiejętność pracy zespołowej, w tym bliskiej współpracy z traktowanymi podmiotowo pracownikami administracyjnymi. Już proces przygotowania wniosku w konkursie grantowym jest wysiłkiem zespołowym, a tym bardziej jego realizacja wymaga przejrzystych procedur zarządzania projektem oraz dobrze kierowanych i różnorodnych zespołów o jasnej strukturze i podziale pracy. Pozostałe wnioski z tej dyskusji są zaskakująco podobne do wymienionych wyższej kluczowych kompetencji tych wnioskodawców, którzy odnieśli sukces. Wskazano bowiem na takie czynniki, jak:

- aktywny udział naukowców w procesach przygotowawczych i szkoleniowych związanych z programami europejskimi,

- umiejętność „sieciowania się” (tworzenie nowych sieci lub dołączanie do sieci już funkcjonujących), bowiem sukces projektu zależy od wzajemnego zaufania i osobistego wsparcia,

- Szerokie rozumienie pojęcia „społeczność badawcza”, ponieważ częścią procesu i kluczem do sukcesu są także odbiorcy zewnętrzni i inni interesariusze,

- skuteczna komunikacja wewnętrzna oraz międzynarodowa.

55 Czworo polskich ekspertów wybranych do Rad Misji programu Horyzont Europa, Ministerstwo Nauki i Szkolnictwa Wyżzzego, https://www.gov.pl/web/nauka/czworo-polskich-ekspertow-wybranych-do-rad-misji-programu-horyzont-europa [dostęp: 7 stycznia 2020 r.]. W gronie tym znaleźli się: Konrad Rydzyński (misja ds. nowotworów), Monika Stankiewicz (misja ds. zdrowych oceanów, mórz, wód przybrzeżnych i śródlądowych), Marta Pogrzeba (misja ds. zdrowej gleby i żywności), Hanna Gronkiewicz-Waltz (misja ds. neutralnych klimatycznie i inteligentnych miast, jako przewodnicząca).

56 Są to państwa członkowskie UE będące jednocześnie członkami OECD.

57 Education at a Glance 2016, OECD Publishing, Paris 2016, s. 43.

58 Analiza wykorzystania przez polskich beneficjentów środków, op. cit., s. 6.

59 Konferencja "PolisSH perspective on Horizon Europe" - podsumowanie, http://polsca.pan.pl/konferencja-polissh-perspective-on-horizon-europe-podsumowanie/ [dostęp: 7 stycznia 2020 r.]. 
Paradoksalnie, nie zawsze krajowe systemy wsparcia dla działalności badawczo-rozwojowej sprzyjają większej aktywności w programach europejskich. Z jednej strony odpowiednio ukształtowane programy krajowe mogą stanowić fazę przygotowawczą (uczenia się, budowania struktur) przed wnioskowaniem i udziałem w bardziej wymagających programach na poziomie europejskim. Z drugiej strony jednak łatwiejsze do zrozumienia i bazujące na prostszych regułach dostępu, z szybszym procesem rozliczania i dostępu do środków, programy krajowe mogą odciągać zainteresowanie i potencjał badawczy od programów europejskich. Ważne jest zatem utrzymanie komplementarności (a nie konkurencyjności) programów krajowych w stosunku do programów europejskich ${ }^{60}$.

\section{Podsumowanie}

Stopniowe dojrzewanie potrzeby głębszej współpracy w sferze naukowo-badawczej w Unii Europejskiej zaowocowało przeznaczaniem na finansowanie tego rodzaju działalności coraz większych środków ze wspólnego budżetu. Finalizowany obecnie program „Horyzont Europa”, jeśli zrealizowane zostaną aktualne uzgodnienia, będzie kolejnym milowym krokiem w tej dziedzinie. Równie ambitne, jak proponowane środki, są cele stawiane przed tym programem. Zgodnie ze wskazaniami przekazanymi przez Przewodniczącą Komisji Europejskiej Ursulę von der Leyen nowej komisarz ds. badań naukowych i innowacji Mariyi Gabriel KE ma zapewnić przepływ środków umożliwiający dokonanie wyjątkowych odkryć i przełomowych innowacji, a także wspierać innowatorów w zdobywaniu znaczącej pozycji rynkowej tak, aby utrzymać globalną konkurencyjność całej Unii. Wśród najważniejszych kierunków zostały wskazane: współpraca z państwami członkowskimi w budowie europejskiej przestrzeni badawczej, zharmonizowanie badań z pozostałymi politykami unijnymi, zwłaszcza polityką przemysłową, wzmacnianie sieci akademickich i podnoszenie międzynarodowej konkurencyjności europejskich uniwersytetów oraz stymulowanie współpracy międzynarodowej w obszarze edukacji, badań naukowych i innowacji61.

Niestety, Polska zdecydowanie nie wykorzystuje swojego potencjału, jeśli chodzi o stopień absorpcji europejskich funduszy na działalność badawczo-rozwojową. Jak to już zaprezentowano na wykresie 1, w ciągu pierwszych 4,5 lat trwania programu „Horyzont 2020” nasz kraj otrzymał 68 mln euro z jego środków. Jest to wprawdzie największa kwota w gronie państw Europy Środkowej, lecz znacznie mniejsze od nas Węgry czy Czechy uzyskały po 46 mln euro. W opinii przedstawicieli Komisji Europejskiej słabością polskich wnioskodawców są: niski poziom wiedzy na temat aplikowania o środki z „Horyzont 2020” oraz niewystarczająca znajomość języka

60 Pozytywnym przykładem takiego kierunku działań może być projekt „Granty na granty”, wspierający podmioty systemu szkolnictwa wyższego i nauki w ubieganiu się o granty z programów badawczych UE. Beneficjentami dofinansowania z tytułu tego projektu mogą być te podmioty, których wnioski zostały już pozytywnie zweryfikowane w konkursie unijnym, Granty na granty - promocja jakości III, Ministerstwo Nauki i Szkolnictwa Wyższego, https://www.gov.pl/web/nauka/granty-na-granty-promocja-jakosci-ii [dostęp: 7 stycznia 2020 r.].

61 President von der Leyen's mission letter to Mariya Gabriel, European Commission, Brussels, 1 December 2019, https://ec.europa.eu/commission/commissioners/sites/comm-cwt2019/files/commissioner_mission_letters/mission-letter-mariya-gabriel-2019_en.pdf [dostęp: 20 stycznia 2020 r.]. 
angielskiego, choć ich mocną stroną jest dokładność w realizacji dofinansowanych projektów oraz lokalizacja w relatywnie dużym i stabilnym nowym państwie członkowskim. Wskazany wyżej udział osób z wyższym wykształceniem w społeczeństwie oraz rozmiary gospodarki mierzone wielkością PKB wskazują, że na tle państw członkowskich UE Polska dysponuje dużym potencjałem naukowym i ekonomicznym, który predestynuje nasz kraj do odegrania istotnej roli w unijnym programie badawczo-rozwojowym. Nasza nauka wymaga jednak wzmożonego wysiłku w kierunku jej umiędzynarodowienia oraz poprawy umiejętności współpracy w wielotematycznych, zróżnicowanych kompetencyjnie zespołach.

Niejednoznaczna jest natomiast ocena wpływu dostępności krajowych środków publicznych na rzecz finansowania działalności badawczo-rozwojowej na skuteczność ubiegania się o środki z programów unijnych. Z jednej strony bowiem łatwiejszy proceduralnie (i językowo) dostęp do źródeł krajowych decyduje o tym, że wnioskodawcy wolą aplikować o to właśnie finansowanie, zamiast startować w bardziej skomplikowanych konkursach międzynarodowych. Z drugiej strony przywoływane wyżej dane statystyczne ${ }^{62}$ wskazują, że im wyższy poziom wydatków na działalność badawczo-rozwojową ze źródeł krajowych, tym większy finalnie udział danego państwa w programach unijnych. Z pewnością zatem kluczowe jest zadbanie o komplementarność pomocy udzielanej z budżetu krajowego w stosunku do działań realizowanych na poziomie europejskim, a także - o tak bardzo podkreślaną w nadchodzącym programie UE - synergię między poszczególnymi funduszami otrzymywanymi z UE.

\section{Bibliografia}

Analiza wykorzystania przez polskich beneficjentów środków w ramach programów zarządzanych centralnie przez Komisję Europejską: Horyzont 2020. Raport końcowy dla Ministerstwa Inwestycji i Rozwoju, Ecorys Polska Sp. z o.o., Warszawa 2017.

M. Boguta, A. Bylicki, Polityka naukowa, badawcza i rozwojowa Unii Europejskiej, Fundacja im. Wojciecha Świętosławskiego na Rzecz Wspierania Nauki i Rozwoju Potencjału Naukowego w Polsce, Gliwice 1998.

M. Diaconu, Business R\&D investments in the EU: Main dynamics and economic effects, "Theoretical and Applied Economics" 2019, Vol. XXVI, No 4(621).

J. Duszyński, M. Szumowski, Nauka w Polsce w obliczu nowej perspektywy finansowej UE 2014-2020 i nowego programu ramowego tej perspektywy - Horizon 2020, "Nauka” 2012, nr 2.

Education at a Glance 2016, OECD Publishing, Paris 2016.

Europe - the Global Centre for Excellent Research, Study requested by the ITRE committee, European Parliament, Brussels 2019.

M. Golińska-Pieszyńska, Polityka wiedzy a współczesne procesy innowacyjne, Wydawnictwo Naukowe Scholar, Warszawa 2009

M.M. Grzelak, I. Laskowska, E. Reszko-Wójtowicz, The Importance of Research Development Expenditure for the Competitiveness of Manufacturing Enterprises in Poland. The Application of Panel Models, "Econometrics/ Ekonometria" 2018, Vol. 22, No 3, https://doi.org/10.15611/eada.2018.3.01

62 From Horizon 2020, op. cit., s. 3. 
Horizon Europe. The Next EU Research \& Innovation Investment Programme (2021-2027). Based on the Commission Proposal for Horizon Europe, the common understanding between co-legislators and the Partial General Approach, both approved in April 2019, European Commission, Brussels 2019.

Key Findings from the Horizon 2020 Interim Evaluation, Directorate-General for Research and Innovation, European Commission, Brussels 2017.

D. Makulska, Kluczowe czynniki rozwoju w gospodarce opartej na wiedzy, „Prace i Materiały Instytutu Rozwoju Gospodarczego SGH" 2012, t. 88, http://www.sgh.waw.pl/instytuty/irg/publikacje/pimirg.

The Measurement of Scientific and Technological Activities: Guidelines for Collecting and Interpreting Innovation Data: Oslo Manual, Third Edition, Working Party of National Experts on Scientific and Technology Indicators, OECD, Paris 2005, https://doi.org/10.1787/9789264013100-en.

Orientations towards the first Strategic Plan for Horizon Europe, European Commission, Brussels 2019.

A. Pollok, G. Wałęga, Kreowanie wiedzy w Polsce przez inwestowanie w badania i rozwój [w:] Inwestowanie w kapitał ludzki, red. S. Borkowska, Zakład Wydawnictw Statystycznych, Warszawa 2007.

Większość działań na rzecz uproszczenia podjętych w zwiq̨zk z programem „Horyzont 2020” przysłużyła się beneficjentom, lecz nadal istnieją możliwości poprawy, Europejski Trybunał Obrachunkowy, sprawozdanie specjalne nr 28/2018.

I. Żukowska, Interdyscyplinarność w polityce badawczej Unii Europejskiej [w:] Studia europejskie. Wyzwania interdyscyplinarności, red. J. Czaputowicz, Wydawnictwa Uniwersytetu Warszawskiego, Warszawa 2014.

\section{Akty prawne}

Communication from the Commission to the Council, the European Parliament, the Economic And Social Committee and the Committee of the Regions: Towards a European research area, $\operatorname{COM(2000)} 6$ final.

Komunikat Komisji do Parlamentu Europejskiego i Rady: Działania w ramach Strategicznego planu realizacji europejskiego partnerstwa na rzecz innowacji sprzyjajacej aktywnemu starzeniu się w dobrym zdrowiu, COM(2012) 83 final.

Komunikat Komisji do Parlamentu Europejskiego, Rady, Europejskiego Komitetu Ekonomiczno-Społecznego oraz Komitetu Regionów: Odnowiony europejski program na rzecz badań i innowacji - szansa Europy na ukształtowanie własnej przyszłości, COM (2018) 306 final.

Komunikat Komisji do Parlamentu Europejskiego, Rady, Europejskiego Komitetu Ekonomiczno-Społecznego oraz Komitetu Regionów: Projekt przewodni strategii Europa 2020: Unia innowacji, COM(2010) 546 final.

Komunikat Komisji do Parlamentu Europejskiego, Rady, Europejskiego Komitetu Ekonomiczno-Społecznego oraz Komitetu Regionów: Stan Unii innowacji na 2012 r. - przyśpieszenie zmian, COM (2013) 149 final.

Rozporządzenie Parlamentu Europejskiego i Rady (UE) nr 1291/2013 z 11 grudnia 2013 r. ustanawiające „Horyzont 2020" - program ramowy w zakresie badań naukowych i innowacji (2014-2020) oraz uchylające decyzję nr 1982/2006/WE, Dz.Urz. UE L 347 z 20 grudnia 2013 r.

Single European Act, OJ L 169 z 29 czerwca 1987 r.

Traktat o Unii Europejskiej oraz traktat o funkcjonowaniu Unii Europejskiej, wersja skonsolidowana, Dz.Urz. UE C 202 z 7 czerwca 2016 r.

Ustawa z 7 lipca 2017 r. o Narodowej Agencji Wymiany Akademickiej, t.j. Dz.U. 2019, poz. 1582.

Ustawa z 20 lipca 2018 r. - Prawo o szkolnictwie wyższym i nauce, Dz.U. poz. 1668. 
Wniosek rozporządzenie Parlamentu Europejskiego i Rady ustanawiające program ramowy w zakresie badań naukowych i innowacji „Horyzont Europa” oraz zasady uczestnictwa i upowszechniania obowiązujące w tym programie, COM(2018) 435 final.

Zielona księga. Europejska Przestrzeń Badawcza: Nowe perspektywy, COM(2007) 161 final.

\section{Strony internetowe}

Http://cerneu.web.cern.ch/horizon2020/structure.

Https://ec.europa.eu.

Https://nawa.gov.pl.

Https://webgate.ec.europa.eu/dashboard.

Http://www.kpk.gov.pl.

Https://www.gov.pl/web/nauka. 